\title{
DIVERSITY AND SPECIES COMPOSITION OF MANGROVES SPECIES IN PILAR, SIARGAO ISLAND, SURIGAO DEL NORTE
}

\author{
Krystel Grace V Padilla ${ }^{1 *}$, Joey G Martizano ${ }^{1}$, June Alexis A. Santos ${ }^{1}$ \\ ${ }^{1 *}$ College of Arts and Sciences, Nueva Ecija University of Science and Technology, \\ Cabanatuan City, Nueva Ecija, 3100, Philippines;
}

"Corresponding Author Krystel Grace V Padilla, e-mail: krystelpadilla27@gmail.com;

Received December 2020; Accepted January 2021; Published February 2021;

DOI: https://doi.org/10.31407/ijees11.115

\begin{abstract}
Mangroves are considered the most significant coastal ecosystem components and among the most productive and biologically complex ecosystems on the planet. The assessment of mangrove species plays a critical role in preserving and protecting the mangroves forest. The study aimed to assess the mangrove species in Pilar, Siargao Island. The belt transect was employed with a dimension of modified $10 \mathrm{~m} \times 12 \mathrm{~m}$ and was installed per quadrat. Eight mangrove species were identified under four families, and these are B. sexanguela, C. decandra, R. apiculata, R. mucronata, A. alba, A. marina, L. littorea, and X. granatum. One species, C. decandra, is categorized by the IUCN as a near-threatened state. Results from the mangroves vegetation structure show that R. apiculata got the highest relative frequency $(26.32 \%)$, density $(35.46 \%)$, and dominance $(55.08 \%)$ therefore, it has the highest importance value (116.85\%). This further implies that R. apiculata is the most essential and acclimated mangrove species in the study area. The species diversity in Pilar, Siargao Island falls under very low diversity $\left(\mathrm{H}^{\prime}=1.63\right)$, which might be attributed to some human-related disturbances. Thus, further consideration in future planning and conservation to increase the mangrove ecosystem's resiliency is needed.
\end{abstract}

Key words: mangroves management, diversity, dominance, conservation status 